\title{
Space Use by Brown Bears (Ursus arctos) in the Sikhote-Alin
}

\author{
Ivan V. Seryodkin*a, Alexey V. Kostyria ${ }^{b}$, \\ John M. Goodrich ${ }^{\mathfrak{c}}$ and Yuriy K. Petrunenko ${ }^{\mathrm{a}}$ \\ aPacific Geographical Institute FEB RAS \\ 7 Radio Str., Vladivostok, 690041, Russia \\ ${ }^{b}$ World Wild Fund for Nature \\ 18 a Verkhneportovaya Str., Vladivostok, 690003, Russia \\ 'Panthera Foundation \\ $408^{\text {th }}$ West Str., New York, 10018, USA
}

Received 23.01.2019, received in revised form 08.07.2019, accepted 23.09.2019

Proper management of brown bear populations (Ursus arctos) requires knowledge of their ecology, including space use. Brown bear spatial patterns are particularly poorly understood in the Russian Far East, due to lack of telemetry studies. The aim of this work was to study space use by brown bears in the Sikhote-Alin region. From 1993 to 2002, we used VHF radiocollars to collect spatial data from nine males (eight adults and one juvenile) and six females (five adults and one juvenile) in the Middle Sikhote-Alin. Fixed Kernel home range size estimates were larger for males $\left(891.34 \pm 346.99 \mathrm{~km}^{2}\right)$ than for females $\left(349.94 \pm 543.06 \mathrm{~km}^{2}\right)$. The juvenile home range sizes were 237.24 and $333.64 \mathrm{~km}^{2}$ for the male and female, respectively. The maximum home range size was for the two-year area of one male $\left(9217.36 \mathrm{~km}^{2}\right)$. The core area sizes varied over a wide range $\left(6.12-358.45 \mathrm{~km}^{2}\right)$. The structure and location of home ranges and their core areas depended upon the seasonal habitat selection of bears, as well as the distribution, abundance, and accessibility of foraging resources. Bears' home ranges overlapped between males and females, as well as between same sex individuals. The results of this work are important for the management of the brown bear population in the Sikhote-Alin.

Keywords: brown bear, home range, radiotelemetry, Sikhote-Alin, Ursus arctos.

Citation: Seryodkin I.V., Kostyria A.V., Goodrich J.M., Petrunenko Y.K. Space use by brown bears (Ursus arctos) in the Sikhote-Alin. J. Sib. Fed. Univ. Biol., 2019, 12(4), 366-384. DOI: 10.17516/1997-1389-0308

(C) Siberian Federal University. All rights reserved

This work is licensed under a Creative Commons Attribution-NonCommercial 4.0 International License (CC BY-NC 4.0).

* Corresponding author E-mail address: seryodkinivan@inbox.ru

ORCID: 0000-0003-4054-9236 (Seryodkin I.), 0000-0002-8784-9845 (Petrunenko Yu.). 


\title{
Использование пространства \\ бурыми медведями (Ursus arctos) \\ на Сихотэ-Алине
}

\author{
И.В. Середкин \\ Д.М. Гудричв ${ }^{\mathrm{B}}$ Ю.К. Петруненко \\ ${ }^{a}$ Тихоокеанский институт географии ДВО РАН \\ Россия, 690041, Владивосток, ул. Радио, 7 \\ ${ }^{6}$ Всемирный фонд дикой природы \\ Россия, 690003, Владивосток, ул. Верхнепортовая, 18 a \\ ${ }^{8}$ Фонд "Пантера" \\ США, 10018, Нью-Йорк, ул. 8-я Западная, 40
}

Грамотное управление популяцией бурого медведя (Ursus arctos L.) требует знания его экологии, в том числе использования животными пространства. Данный вопрос на Дальнем Востоке России изучен недостаточно из-за небольшого количества программ, применяющих телеметрические методы исследования бурых медведей. Целью работы являлось изучение особенностей использования пространства бурыми медведями на Сихотэ-Алине. В 1993 2002 г2. на Среднем Сихотэ-Алине с помощью радиотелеметрии вели наблюдения за восемью взрослыми и одним молодым самиами, пятью взросльми и одной молодой самками, оснащенными очейниками с УКВ-радиопередатчиками. У взрослых особей средний размер годовых участков обитания, полученный с помощью метода «фиксированный кернел», был

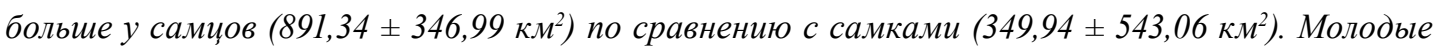
животные в течение года занимали участки площадью 237,24 и 333,64 км² у самиа и самки соответственно. Максимальный размер имел двухлетний участок самиа (9217,36 км²). Размер ядерных зон участков обитания варьировал в широких пределах (6,12-358,45 км²). Структура и географическое расположение участков обитания и их ядерных зон зависели от сезонного выбора медведями местообитаний, распределения, обилия и доступности кормов. Между собой перекрывались участки обитания как самиов с самками, так и особей одного пола. Полученные результаты важны для управления популяцией бурого медведя на Сихотэ-Алине.

Ключевые слова: бурый медведь, участок обитания, радиотелеметрия, Сихотэ-Алинь, Ursus arctos.

Цитирование: Середкин, И.В. Использование пространства бурыми медведями (Ursus arctos) на Сихотэ-Алине / И.В. Середкин, А.В. Костыря, Д.М. Гудрич, Ю.К. Петруненко // Журн. Сиб. федер. ун-т. Биология, 2019. 12(4). С. 366384. DOI: 10.17516/1997-1389-0308

\section{Введение}

Бурый медведь (Ursus arctos L.) на Сихотэ-Алине играет важную роль в лесных экосистемах и имеет статус охотничьего вида.
Угрозы для благополучного существования его популяции - сокращение мест обитания, браконьерство и подрыв кормовой базы в результате деятельности человека (Середкин,

$$
-367-
$$


Пикунов, 2009). В этих условиях необходима научно обоснованная стратегия управления популяцией, которая бы гарантировала ее сохранение в будущем.

Для управления популяцией бурого медведя большое значение имеет знание экологии этого животного в данном регионе. Одной из важнейших экологических характеристик популяции служит использование животными пространства, в частности участков обитания (Dahle, Swenson, 2003; Rigg, 2005; Popescu et al., 2017). Участок обитания - понятие, которое является фундаментальным для разработки основных современных концепций в исследованиях использования пространства дикими животными. Участок обитания определяют как пространство, которое осваивает животное в процессе его нормальной жизнедеятельности, связанной с перемещениями в поисках пищи, участием в размножении и выращиванием потомства (Burt, 1943). Знание размеров участков обитания животных необходимо для определения площадей пространства, достаточных для существования отдельных особей и их группировок, что важно для сохранения животных и планирования особо охраняемых природных территорий (Gula et al., 1998; Zedrosser et al., 1999; Proctor et al., 2002). Размер участка обитания - также параметр, применяемый в расчетах численности животных (Zedrosser et al., 1999; Jerina et al., 2003; Popescu et al., 2017).

Интенсивное освоение человеком местообитаний медведей влечет за собой перераспределение животных, изменение их перемещений, активности, смещение участков обитания и изменение размеров осваиваемого пространства (Smith, 2002; Fortin et al., 2016; Skuban et al., 2016). Мониторинг перечисленных параметров необходим для выработки рекомендаций для сохранения популяции бурого медведя и его рационального исполь- зования. Метод радиотелеметрии позволяет оценить эти аспекты экологии бурого медведя.

Использование пространства и перемещения бурого медведя на Дальнем Востоке России недостаточно изучены, поскольку программ, применяющих методы радиотелеметрии и спутникового слежения животных, было относительно не много (Середкин, 2014). Ранее в Приморском крае (Seryodkin et al., 2014), на Камчатке и Сахалине (Seryodkin et al., 2017) осуществляли лишь отдельные исследования по данной тематике.

Цель настоящей работы - изучение особенностей использования пространства бурыми медведями на Сихотэ-Алине. Для достижения цели были поставлены следующие задачи: определить размеры, структуру и географическое расположение участков обитания медведей за годовой, двух- и трехлетний периоды, степень перекрывания годовых участков, степень совместного использования пространства соседствующими особями.

\section{Материал и методы}

Исследования проводили на восточном макросклоне Среднего Сихотэ-Алиня (Приморский край) в бассейнах рек, впадающих в Японское море. Территория ограничивалась с запада главным водораздельным хребтом, разделяющим западный и восточный макросклоны, с востока - морским побережьем, на юге - координатами $44,73^{\circ}$ с.ш., на севере $45,73^{\circ}$ с.ш.

Сихотэ-Алинь представляет собой сложную систему горных хребтов, речных долин, межгорных депрессий и горных плато, он относится к средневысотным горам со средней высотой в районе исследования 600-800 м над уровнем моря (Ветренников, 1976). Благодаря ярко выраженному разнообразию климатических, высотных и почвенных условий, а так- 
же своему положению на стыке различных биогеографических районов Азии, СихотэАлинь характеризуется одним из наиболее высоких в России биологическим разнообразием видов и природных сообществ. В горах преобладают кедрово-широколиственные и темнохвойные леса, а на побережье моря широколиственные леса. Главными лесообразователями являются сосна корейская (Pinus koraiensis Nakai.), ель аянская (Picea ajanensis (Lindl. et Gord.)), пихта почкочешуйная (Abies nephrolepis (Trautv.) Maxim.), лиственница даурская (Larix dahurica Turcz. ex Trautv.), ясень маньчжурский (Fraxinus mandshurica Rupr.) и дуб монгольский (Quercus mongolica Fisch. ex Ledeb.).

Отлов хищников проводили в СихотэАлинском заповеднике с помощью лапозахватывающих ловушек Олдрича. Этот способ отлова медведей широко распространен в мире (Jonkel, 1993) и успешно применялся в России
(Середкин и др., 2005; Середкин, Пачковский, 2006). Ловушка Олдрича представляет собой стальной трос диаметром 6,2 мм, затягивающийся на лапе животного при помощи активируемой им пружины. Второй конец троса зафиксирован, но свободно вращается на вертлюге, что предотвращает травмирование зверя. Ловушки устанавливали на тропах или у приманки (рыба, мясо копытных млекопитающих).

Медведей обездвиживали при помощи ружья системы Telinject, стреляющего шприцами. В качестве анестезирующего препарата использовали золетил (Zoletil, Virbac, Франция; 50 \% тилетамин гидрохлорид + 50 \% золазепам гидрохлорид) в рекомендуемых дозах (Kreeger, 1996; Середкин и др., 2005).

В 1993-2001 гг. отловлены и оснащены радиоошейниками 15 медведей, из них восемь - взрослые самцы, пять - взрослые самки и две молодые, но самостоятельные осо-

Таблица 1. Характеристика бурых медведей, отловленных и помеченных радиоошейниками в СихотэАлинском заповеднике

Table 1. Characteristics of brown bears caught and radio-collared in the Sikhote-Alin Reserve

\begin{tabular}{cccccc}
\hline № медведя & Дата отлова & Пол & Возраст, лет & Масса, кг & Длина тела, см \\
\hline I & 05.07 .1993 & самец & 9 & 240 & 224 \\
II & 19.07 .1993 & самец & 11 & 305 & 222 \\
III & 03.09 .1993 & самец & $2-3$ & 143 & 145 \\
IV & 10.09 .1993 & самец & 12 & 268 & 200 \\
V & 19.05 .1994 & самец & 16 & 363 & 206 \\
VI & 31.05 .1994 & самец & 8 & 220 & 179 \\
VII & 04.06 .1994 & самка & 7 & 138 & 175 \\
VIII & 13.06 .1996 & самка & 9 & 95 & 166 \\
IX & 29.05 .1997 & самка & 4 & 141 & 185 \\
X & 17.09 .1999 & самка & 8 & 204 & 218,5 \\
XI & 23.10 .1999 & самец & 8 & 215 & 185,5 \\
XII & 31.10 .1999 & самка & 9 & 204 & 214,5 \\
XIII & 31.10 .1999 & самец & 8 & 256 & 198 \\
XIV & 19.05 .2000 & самец & 13 & 93 & 151 \\
XV & 31.05 .2001 & самка & 3 &
\end{tabular}


би (самец и самка) 2-3 лет (табл. 1). Возраст зверей определяли по числу линий прироста в зубном цементе передних премоляров, не несущих функциональную нагрузку (Клевезаль, 1988). Самку Х в 1999 г. сопровождали два медвежонка первого года жизни, а в 2000 г. - соответственно второго года. Также было известно, что медведица VIII в 1996 г. имела потомство, поскольку была лактирующей.

Использовали УКВ-радиоошейники систем MOD-400 и MOD-500 (Telonics, Mesa, Arizona, USA), продолжительность работы которых составляла 3-5 лет. Радиослежение осуществляли при помощи радиоприемника (TR-2, Telonics, Mesa, Arizona), направленных H-антенн (RA-2A, Telonics, Mesa, Arizona, USA) и трехсегментных Яги антенн (RA-17, Telonics, Mesa, Arizona, USA). Радиопринимающее оборудование настраивали на индивидуальные частоты радиопередатчиков. Поиск медведей проводили на пеших маршрутах, а также с помощью вертолетов Ми-2, Ми-8 и самолета Ан-2 не менее двух раз в неделю в светлое время суток. Местонахождение животных определяли методом триангуляции с земли и облетом по кругу с уменьшающимся радиусом при пеленгации с летательного аппарата. В анализ участков обитания вошли координаты 742 мест пребывания медведей (табл. 2), использовали не более одной позиции одного животного в сутки. Место расположения берлоги учитывали в анализе участка только один раз.

Построение контуров участков обитания медведей и расчет их площади производили методом «фиксированный кернел» (Van Winkle, 1975; Worton, 1989). Метод заключается в статистическом расчете вероятности нахождения животного в любой точке исследуемого пространства с вероятностью от 1 до $100 \%$. Участком обитания считали пространство, вероятность нахождения животного в котором составляла $95 \%$. Для расчета параметра сглаживания (smoothing parameter) проводили перекрестную проверку методом наименьших квадратов (Least Square Cross Validation) с построением двумерной матрицы, позволяющей рассчитывать параметр сглаживания вдоль вращающейся оси для каждого участка обитания (Kernohan et al., 2001; Gitzen, Millspaugh, 2003; Gitzen et al., 2006). Так как часть участков обитания медведей располагалась вдоль морского побережья, полигоны построенных участков могли распространяться на акваторию моря, непригодную для обитания животных. В этих случаях часть полигона, занятую морем, обрезали и не использовали в анализе.

Методом «фиксированный кернел» рассчитывали ядерные зоны участков обитания - пространства с относительно высокой интенсивностью использования животными. В отличие от классического представления о ядерной зоне как о пространстве с $50 \%$-й вероятностью нахождения в нем животного, применяли контур кернел, в котором разница между ожидаемой и действительной площадями была максимальной (Powell, 2000). В программе QGIS (v. 3.4.1) определены площади участков обитания и ядерных зон. Для каждого участка установлена доля площади ядерной зоны от площади участка обитания (в процентах).

Для оценки изменений в использовании пространства тремя медведями (IV, X, XIV), за которыми следили в течение двух лет, рассчитали степень перекрывания двух их годовых участков обитания и ядерных зон между собой по формуле:

$$
C=\sqrt{\frac{O}{A} \times \frac{O}{B}} \times 100
$$


где С - среднее геометрическое перекрывание участков (или их ядерных зон), в процентах; $\mathrm{O}$ - площадь общего перекрывания двух участков обитания (или их ядерных зон); А площадь первого участка обитания (или его ядерной зоны); В - площадь второго участка обитания (или его ядерной зоны) (Minta, 1993).

Для определения степени совместного использования пространства двумя соседствующими животными (участки которых частично перекрывались) применяли индекс перекрывания участков обитания UDOI (utilization distribution overlap index). Данный индекс позволяет сравнить интенсивность использования пространства двумя животными в пределах зоны перекрывания их участков (Fieberg, Kochanny, 2005). Исследования показали, что индекс UDOI по сравнению с другими индексами наиболее точно коррелирует с частотой встреч между животными, что наиболее точно позволяет определить степень перекрывания участков обитания (Robert et al., 2012).

Построение индивидуального участка, ядерной зоны и расчет индекса перекрывания

Таблица 2. Размеры участков обитания бурых медведей на Сихотэ-Алине в 1993-2002 гг.

Table 2. Home range area of brown bears in the Sikhote-Alin in 1993-2002

\begin{tabular}{|c|c|c|c|c|c|c|}
\hline $\begin{array}{c}\text { № } \\
\text { медведя }\end{array}$ & Участок & Период исследования & $\begin{array}{c}\text { Количество } \\
\text { позиций }\end{array}$ & $\begin{array}{c}\text { Площадь } \\
\text { участка } \\
(95 \%), \text { км}^{2}\end{array}$ & $\begin{array}{c}\text { Площадь } \\
\text { ядерной } \\
\text { зоны, км² }\end{array}$ & $\begin{array}{c}\text { Соотношение } \\
\text { площадей ядерной } \\
\text { зоны и участка, \% }\end{array}$ \\
\hline I & Годовой & $05.07 .1993-08.08 .1994$ & 29 & 1058,11 & 70,56 & 6,67 \\
\hline I & Двухлетний & 05.07.1993-27.07.1995 & 37 & 997,97 & 88,61 & 8,88 \\
\hline II & Годовой & 19.07.1993-08.12.1993 & 21 & 1303,32 & 196,88 & 15,11 \\
\hline III & Годовой & 03.09.1993-10.09.1994 & 87 & 237,24 & 33,36 & 14,06 \\
\hline IV & Годовой & $10.09 .1993-08.09 .1994$ & 81 & 592,02 & 137,20 & 23,17 \\
\hline IV & Годовой & $10.09 .1994-10.06 .1995$ & 29 & 887,58 & 70,06 & 7,89 \\
\hline IV & Двухлетний & $10.09 .1993-10.06 .1995$ & 110 & 811,77 & 90,89 & 11,20 \\
\hline $\mathrm{V}$ & Годовой & 19.05.1994-06.05.1995 & 32 & 1559,19 & 358,45 & 22,99 \\
\hline VI & Годовой & $31.05 .1994-25.05 .1995$ & 34 & 683,62 & 216,11 & 31,61 \\
\hline VII & Годовой & 04.06.1994-06.05.1995 & 31 & 187,95 & 13,46 & 7,16 \\
\hline VII & Трехлетний & 04.06.1994-09.07.1997 & 49 & 466,13 & 40,56 & 8,70 \\
\hline VIII & Трехлетний & 13.06.1996-06.11.1999 & 34 & 456,61 & 38,22 & 8,37 \\
\hline IX & Годовой & 11.06.1997-13.07.1998 & 45 & 118,89 & 35,98 & 30,27 \\
\hline $\mathrm{X}$ & Годовой & 17.09.1999-10.08.2000 & 30 & 1317,03 & 203,17 & 15,43 \\
\hline $\mathrm{X}$ & Годовой & $19.08 .2000-15.08 .2001$ & 30 & 64,87 & 6,12 & 9,43 \\
\hline $\mathrm{X}$ & Двухлетний & 17.09.1999-15.08.2001 & 60 & 390,00 & 33,39 & 8,56 \\
\hline XI & Двухлетний & 23.10.1999-27.10.2001 & 28 & 9217,36 & 170,05 & 1,84 \\
\hline XII & Годовой & 31.10.1999-28.08.2000 & 68 & 60,95 & 7,28 & 11,94 \\
\hline XIII & Годовой & $31.10 .1999-23.11 .2000$ & 61 & 701,59 & 50,76 & 7,24 \\
\hline XIV & Годовой & 19.05.2000-07.12.2000 & 23 & 588,13 & 90,58 & 15,40 \\
\hline XIV & Годовой & 28.03.2001-12.04.2002 & 23 & 648,53 & 111,74 & 17,23 \\
\hline XIV & Двухлетний & $19.05 .2000-12.04 .2002$ & 46 & 684,41 & 280,69 & 41,01 \\
\hline XV & Годовой & $31.05 .2001-23.06 .2002$ & 30 & 333,64 & 54,83 & 16,43 \\
\hline
\end{tabular}


UDOI проводили в программе R (v. 3.0.2) (R Development Core Team, 2015). Ядерная зона была рассчитана с помощью кода, находящегося в свободном доступе (Wilson et al., 2010; Core area..., 2017). Индексы перекрывания были рассчитаны с помощью кода для программы R (Fieberg, 2014). При работе в R использованы пакеты: splancs (Rowlingson, Diggle, 1993), spatstat (Baddeley, Turner, 2005), adehabitat (Calenge, 2006), MASS (Venables, Ripley, 2002) и MCMCpack (Martin, Quinn, 2006).

Для статистической оценки достоверности разницы между значениями размеров участков обитания и их ядерных зон между взрослыми особями по половой принадлежности применяли критерий Манна-Уитни.

Во время слежения за мечеными животными на территории исследования велись наблюдения за распределением, обилием и доступностью важных для медведей кормов, которые отражены в отдельной публикации (Середкин и др., 2012).

\section{Результаты}

Размеры годовых участков обитания

Проведен анализ девяти годовых участков обитания семи взрослых самцов (табл. 2). Средний размер участков составил 891,34 км² $\left(\mathrm{SD}=346,99\right.$ км$\left.^{2}\right)$ при максимальной площади 1559,19 км². Ядерные зоны участков самцов в среднем имели площадь 144,70 км² $^{2}$ $\left(\mathrm{SD}=98,41 \mathrm{\kappa м}^{2}\right)$.

Средний размер пяти годовых участков обитания четырех взрослых самок составил

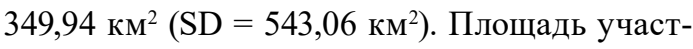
ков широко варьировала, при этом максимальный размер имел участок имевшей медвежат медведицы Х в 1999-2000 гг. (табл. 2; рис. 1).

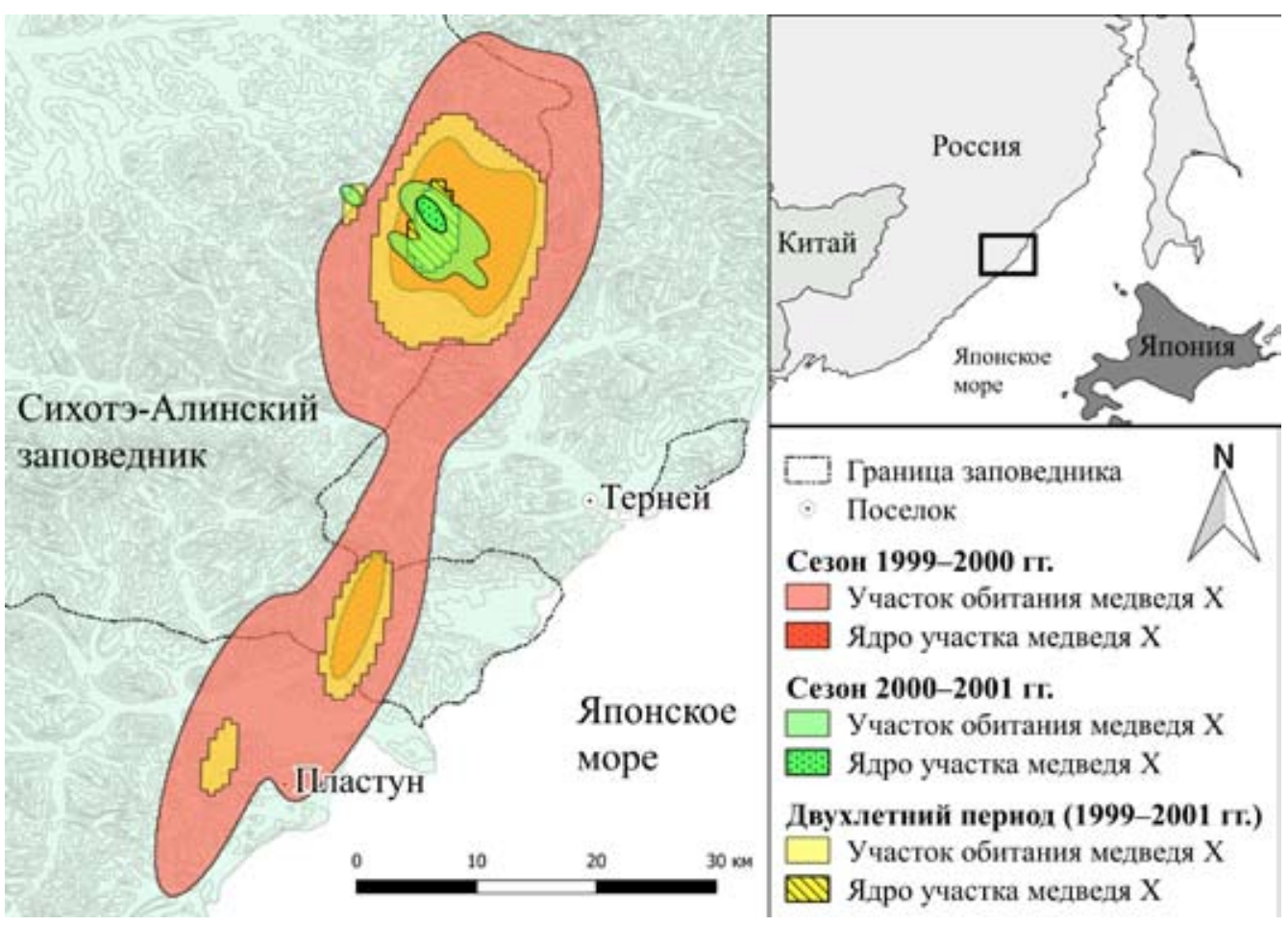

Рис. 1. Двухлетний и годовые участки обитания и их ядерные зоны взрослой самки бурого медведя X на Сихотэ-Алине

Fig. 1. Two-year and annual home ranges and core areas of the adult female brown bear X in the Sikhote-Alin 
Ядерные зоны участков самок располагались на площади от 6,12 до 203,17 км² при среднем значении 53,20 км² $\left(\mathrm{SD}=84,69\right.$ км²$^{2}$.

Средний размер участков обитания у взрослых самцов был достоверно больше, чем у взрослых самок $(U=37, p=0,03)$. Ядерные зоны участков также были больше у взрослых самцов $(\mathrm{U}=38, \mathrm{p}=0,02)$.

Молодые животные имели годовые участки обитания размером 237,24 и 333,64 км² у самца III и самки XV соответственно (табл. 2).

Соотношение площади ядерной зоны к площади участка обитания составило в среднем $16,37 \%(\mathrm{SD}=8,48 \%)$ для взрослых самцов и $14,84 \%(\mathrm{SD}=9,15 \%)$ - для взрослых самок. Минимального значения $(6,67 \%)$ данный показатель достигал у самца I, имевшего относительно большой размер участка обитания, а максимального - у самца VI (31,61 \%), участок которого был относительно небольшим (табл. 2).

\section{Структура}

и географическое расположение

годовых участков обитания

Участки обитания взрослых самцов состояли из одного цельного полигона 5 раз, из двух -3 раза и из четырех полигонов - 1 раз. Когда участки состояли из двух полигонов, расстояние между ними было относительно небольшим: 1,3 км у самца I (рис. 2), 6 км у самца VI и 9,2 км у самца XIV в 2001-2002 гг. У самца XIII, участок которого был фрагментирован на четыре части, наиболее удаленные полигоны отстояли на 11,7 км.

Участки взрослых самок состояли из одного полигона 1 раз (медведь Х в 19992000 гг., рис. 1), из двух - 2 раза (самка $X$ в 2000-2001 гг. и медведица XII) и трех - 2 раза (самки VII и IX). У самок IX, X и XII дистанция между полигонами равнялась 2-5 км, тогда как у самки VII между крайними полигонами было 26 км.

У молодого самца III участок обитания состоял из шести полигонов, расстояние между двумя наиболее удаленными из них было равно 41,8 км (рис. 2). У молодой самки XV участок представлял собой один полигон.

Ядерные зоны годовых участков обитания медведей имели один (10 раз) или два (6 раз) полигона. Между ними было от 1 (самец VI) до 28,8 км (самка X в 1999-2000 гг., рис. 1).

Семь участков обитания медведей (пять - самцов и два - самок) находились внутри бассейна одной из трех крупных рек (Джигитовка, Серебрянка, Заболоченная), расположенных на территории исследования, или их притоков (например, самцы III, IV в бассейне Джигитовки, рис. 2). При этом границы участков не пересекали водораздельные хребты этих рек и часто простирались вдоль них. Остальные девять участков не были расположены в бассейне только одной реки, водораздельные хребты не являлись для медведей преградой в их перемещениях (например, участок самки X в 1999-2000 гг., рис. 1). Границы участков пяти самцов и двух самок подходили к руслу p. Джигитовка со стороны левобережья, но не пересекали реку. Десять участков медведей включали морское побережье (например, самцы I, II, IV, рис. 2).

Ядерные зоны пяти участков обитания (трех взрослых самцов и двух взрослых самок) располагались исключительно в верхнем течении рек в близких к водоразделам местах, ядерные зоны участков двух медведей (взрослой самки и молодого самца) были расположены в приустьевых частях рек и на морском побережье, ядерные зоны остальных участков включали разные по высоте части речных бассейнов. 


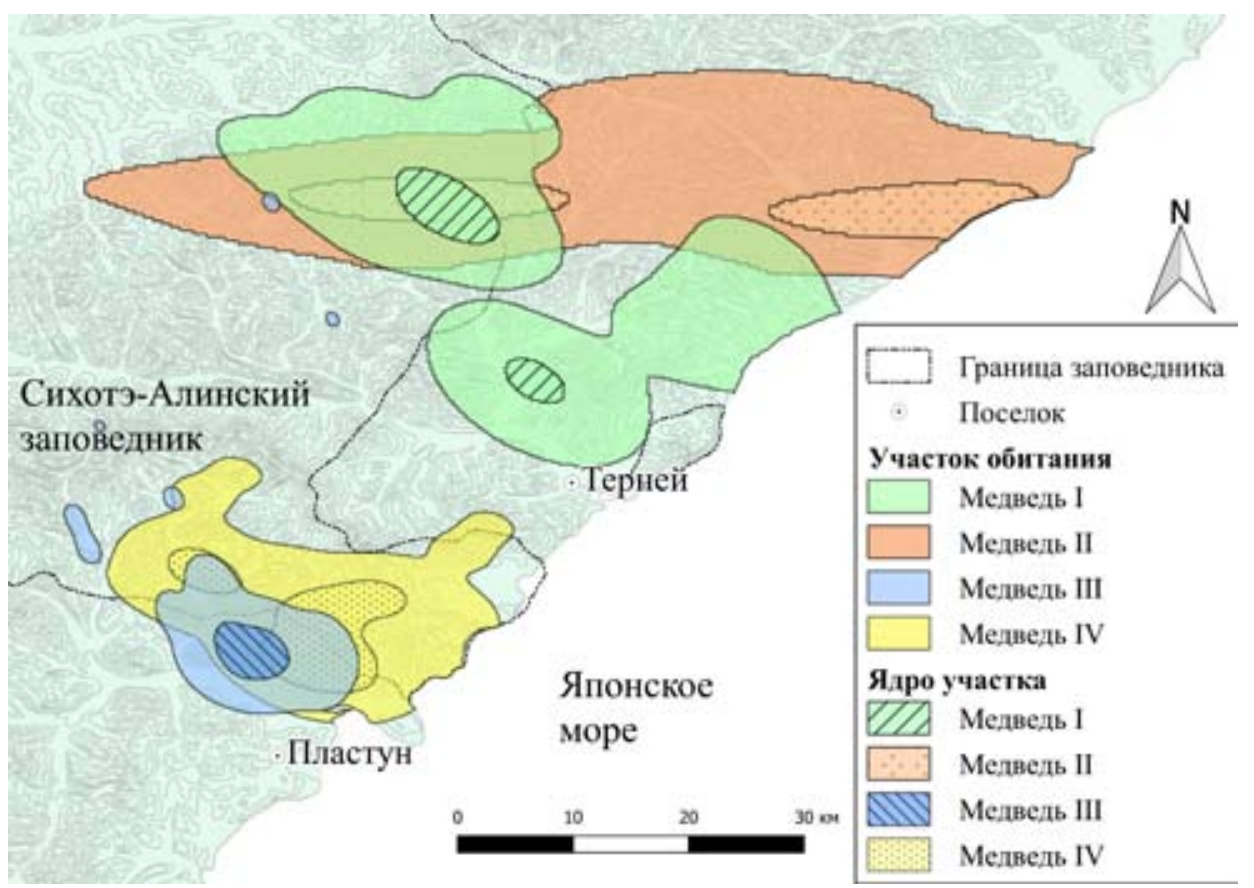

Рис. 2. Годовые участки обитания и их ядерные зоны четырех самцов бурого медведя в 1993-1994 гг. на Сихотэ-Алине

Fig. 2. Annual home ranges and core areas of four brown bear males in 1993-1994 in the Sikhote-Alin

Двух-трехлетние участки обитания и перекрывания годовых участков индивидуально для каждого животного

Проанализированы семь участков обитания медведей за период более 1 года (от 2 до 3 лет). Средний размер участков четырех взрослых самцов составил 2927,88 км² $\left(\mathrm{SD}=4194,97\right.$ км$\left.^{2}\right)$. Средняя площадь ядерных зон участков самцов была 157,56 км² $\left(\mathrm{SD}=90,40\right.$ км²$\left.^{2}\right)$. Размер ядерной зоны участка самца XI составил лишь 1,84 \% от общего размера его участка, который был максимальным в наших исследованиях. У самца XIV, напротив, ядерная зона занимала существенную часть участка (табл. 2). Участки обитания трех самок имели среднюю площадь 437,58 км² $\left(\mathrm{SD}=41,48 \mathrm{\kappa м}^{2}\right)$, а их ядерные зоны - 37,39 км² $\left(\mathrm{SD}=3,66 \kappa^{2}\right)$.

Взрослый самец XI (табл. 2) в течение двух лет перемещался с юга на север. Он поочередно обитал в бассейнах нескольких крупных рек (Джигитовка, Серебрянка, Таежная, Кема, Пещерная), пересекал крупные водоразделы с высотой гор около 1000 м над уровнем моря. Линейная дистанция между крайними точками участка его обитания составила 202 км.

Двух-трехлетние участки только двух медведей имели по одному полигону (самцы IV и XI), остальные участки имели по три полигона, один из которых во всех случаях был относительно крупнее двух других. Наибольшее расстояние (58 км) между полигонами участка было у самки X (рис. 1). Ядерные зоны участков состояли из одного (4 раза) или двух (3 раза) полигонов, расстояние между которыми достигало 37 км (у самца XI). В отличие от некоторых годовых двух- и трехлетние участки не были расположены в бассейне одной из крупных 
рек и у всех животных включали крупные водоразделы.

У трех особей удалось оценить степень перекрывания их годовых участков обитания (по два). Значительно перекрывались участки самца IV (на 68,05 \%) и самца XIV (на 68,62 \%). $\mathrm{Y}$ самки X была незначительная степень перекрывания двух годовых участков (1999-2000 и 2000-2001 гг.), которая составила 7,09 \% (рис. 1). Ядерные зоны годовых участков у этих трех животных перекрывались на 15,53, 25,26 и $17,35 \%$ соответственно.

Перекрывание участков обитания соседствуюших особей

В сезон 1993-1994 гг. удалось оценить степень перекрывания годовых участков между пятью парами особей, в 1994-1995 гг. - между восьмью парами и в 1999-2000 гг. - между шестью парами медведей (табл. 3). Между взрослыми самцами максимальное значение степени перекрывания (UDOI) составило 0,33 для участков обитания и 0,21 - для их ядер. Степень перекрывания участков между взрослыми самцами и самками была больше и доходила до 0,61 для участков и 0,41 - для ядер. В 1994-1995 гг. годовой участок самки VII перекрывался с участками четырех самцов, трое из которых были взрослыми. Ядерные зоны участков обитания у всех соседствующих особей перекрывались несущественно (табл. 3, рис. 2).

Табл. 3. Степень совместного использования пространства бурыми медведями на Сихотэ-Алине Table 3. The degree of joint space use by brown bears in the Sikhote-Alin

\begin{tabular}{cccc}
\hline Номера сравниваемых & Период для & \multicolumn{2}{c}{ UDOI } \\
\cline { 3 - 4 } сравнедей & $1993-1994$ & Участок $(95 \%)$ & Ядерная зона \\
\hline I, II & $1993-1994$ & 0,17 & 0,14 \\
III, IV & $1993-1994$ & 0,45 & 0,05 \\
III, V & $1993-1994$ & 0,36 & 0,001 \\
IV, V & $1993-1994$ & 0,33 & 0,21 \\
IV, VII & $1994-1995$ & 0,43 & 0,12 \\
I, VII & $1994-1995$ & 0,001 & 0 \\
III, IV & $1994-1995$ & 0,06 & 0 \\
III, VII & $1994-1995$ & 0,47 & 0 \\
IV, V & $1994-1995$ & 0,23 & 0,17 \\
IV, VI & $1994-1995$ & 0,28 & 0,095 \\
IV, VII & $1994-1995$ & 0,18 & 0 \\
V, VI & $1994-1995$ & 0,09 & 0 \\
V, VII & $1999-2000$ & 0,61 & 0,41 \\
X, XII & $1999-2000$ & 0,01 & 0 \\
X, XIII & $1999-2000$ & 0,21 & 0 \\
X, XV & $1999-2000$ & 0,04 & 0 \\
XII, XIII & $1999-2000$ & 0,12 & 0 \\
XII, XV & $1999-2000$ & 0,16 & 0 \\
XIII, XV & & 0,23 & 0 \\
\hline
\end{tabular}




\section{Обсуждение}

Размеры годовых участков обитания

Размеры участков обитания бурых медведей на Сихотэ-Алине оказались больше, чем в других регионах Дальнего Востока, где данный вопрос изучали с помощью телеметрии. Так, на Сахалине и Камчатке годовые участки самок не превышали 27,6 км² (Seryodkin et al., 2017), а в Японии составляли 28,1-59,0 км² (Mano, 1994; Sato et al., 2008). Между размерами годовых участков медведей и продуктивностью угодий доказано наличие обратной связи (McLoughlin et al., 1999). Относительно небольшие размеры участков обитания медведей на Камчатке и Сахалине могут объясняться тем, что в этих регионах корма медведей имеются в изобилии и сконцентрированы, особенно во время нереста лососей (Seryodkin et al., 2017). Подобная ситуация наблюдается на северо-западе Северной Америки, где участки обитания бурых медведей составляют в среднем 24,4 и 14,3 км² на острове

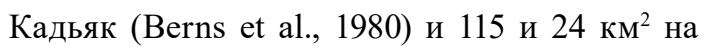
острове Адмиралти (Schoen et al., 1986) для самцов и самок соответственно.

На Сихотэ-Алине лососи в рационе медведей не имеют большого значения, тогда как основными нажировочными кормами являются орехи сосны корейской и желуди дуба монгольского (Бромлей, 1965; Середкин, 2015). Распределение данных кормов и их урожайность неравномерны. Медведи на Сихотэ-Алине в поисках пищи способны проходить большие расстояния (Бромлей, 1965; Середкин и др., 2012, 2014), что определяет относительно крупные размеры участков их обитания.

Размеры участков обитания медведей в наших исследованиях наиболее сопоставимы с таковыми, полученными в Северной Америке: в Альберте (Russell et al., 1979), в Вайоминге (Blanchard, Knight, 1991) и на се- вере Аляски (Reynolds, 1980; Collins et al., 2005), где средние значения составляют для самцов 872-948 км² и для самок 225-356 км². Подобные размеры участков не являются для бурого медведя предельными. Так, в Канаде (Северо-Западные территории) средние пло-

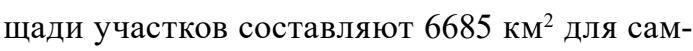
цов и 2074 км$^{2}$ для самок (McLoughlin et al., 1999).

На территории исследования ядерные зоны представляли собой относительно большие части участков медведей, чем на Камчатке и Сахалине, где у самок ядерные зоны в среднем занимали только 5,6 \% площади участков (Seryodkin et al., 2017) против $14,84 \%$ на Сихотэ-Алине. Предпочитаемые животными небольшие по площади места с наилучшими условиями обитания, особенно в отношении наличия и доступности кормов, более характерны для Камчатки и Сахалина, тогда как на исследуемой территории медведи реже подолгу держатся столь локально. По всей видимости, в первую очередь это связано со спецификой распределения кормов на Сихотэ-Алине: отсутствием мест, где пищевые ресурсы быстро возобновляются (как на нерестовых реках). Потребив большую часть кормов в одном месте, медведи вынуждены переходить на другое.

Тенденция уменьшения показателя относительного размера ядерной зоны с увеличением площади осваиваемого медведем пространства в нашем исследовании связана с тем, что большая часть крупного участка обитания осваивается животным недостаточно интенсивно и используется только для транзитных перемещений между предпочитаемыми местами обитания.

Больший размер участков обитания самцов по сравнению с самками, отмеченный на Сихотэ-Алине, - обычное явление для бурых медведей (Pearson, 1975; Servheen, 1983; 
Bjarvall et al., 1990; McLoughlin et al., 1999). Редкий случай обратного явления зафиксирован для медведей острова Кадьяк (Glenn, Miller, 1980). Потребность в относительно больших участках у самцов объясняется тем, что они имеют повышенные энергетические потребности по сравнению с самками и, соответственно, нуждаются в большей площади для сбора пищи (McNab, 1963).

\section{Структура}

и географическое расположение

годовых участков обитания

Структура участка обитания, количество и расположение полигонов в нем зависят от сезонного выбора медведями местообитаний (кормовые, берложные стации), распределения кормов. Участок состоит из одного цельного полигона при относительно равномерном использовании животным пространства. Более одного полигона отмечается для участков обитания медведей и в других регионах Дальнего Востока (Seryodkin et al., 2017), что связано с наличием удаленных друг от друга мест, предпочтительно посещаемых животными в разные сезоны.

В нашем исследовании два полигона годового участка имели наибольшую удаленность у самца III. Один из них был расположен в месте обитания медведя в летне-осенний период (нижнее течение р. Джигитовка), а второй - в районе его залегания в берлогу (верхнее течение одного из притоков р. Серебрянка). Известно, что бурые медведи на Сихотэ-Алине могут устраивать берлоги на большом удалении от мест их нажировки осенью (Абрамов, 1972; Кучеренко, 1983; Юдин, 1993; Середкин и др., 2014).

Исследование показало, что у части медведей, как у самцов, так и у самок, границы участков проходят по водораздельным хребтам. Подобные наблюдения отмечены также для бурых медведей Северного Кавказа (Бобырь, 1991) и Центральной Азии (Жиряков, Грачев, 1993). Возможно, эта особенность характерна для горных регионов, где речные бассейны ограничены выраженными хребтами. Тем не менее не для всех медведей водораздельные хребты были преградой.

В случаях, когда участки обитания животных располагались по одну сторону от p. Джигитовка, лес по разные стороны реки был качественно различным и имел разную степень антропогенного воздействия на него. Медведи обитали на левобережье, входящем территориально в состав Сихотэ-Алинского заповедника, где сохранились нетронутые рубками кедрово-широколиственные леса. По правую сторону реки лес был менее продуктивным, а фактор беспокойства - более выраженным. По сути, граница участков обитания проходила в этих случаях по границе заповедника.

Двух-трехлетние участки обитания и перекрывание годовых участков индивидуально для каждого животного

Участки обитания как самцов, так и самок за двух-трехлетний период имели больший средний размер, чем средний размер годовых участков. Смещение годовых участков увеличивает площадь, осваиваемую животными за более длительный период. Тем не менее средний размер ядерных зон не выростал при увеличении периода наблюдения за животными. В данном аспекте увеличение площади участка обитания не влияет на размер наиболее интенсивно используемой его части.

Большое расстояние между двумя полигонами самки $X$ (рис. 1) объясняется тем, что осенью 1999 г. она с медвежатами уходила для нажировки в бассейн р. Куналейка, где был локальный высокий урожай желудя 
(Середкин и др., 2012), после чего вернулась в бассейн р. Заболоченная, где и провела оставшуюся часть периода наблюдения за ней. Поскольку два этих места обитания медведицы разделяли 58 км, степень перекрывания двух ее годовых участков была незначительной (рис. 2).

Увеличение участка взрослого самца IV во второй год наблюдения за ним по сравнению с первым произошло за счет захода животного в бассейн соседней реки. Значительное перекрывание двух годовых участков обитания у каждого из двух самцов указывает на то, что медведи в течение длительного времени могут держаться определенных территорий, на которых имеют статус резидентных особей. Данное утверждение справедливо и для других частей ареала бурого медведя (Мордосов, 1993; Wakkinen, Kasworm, 2004; Pop et al., 2012).

Незначительное перекрывание ядерных зон годовых участков медведей в разные годы связано с особенностями распределения кормов в эти периоды, в первую очередь орехов сосны корейской, желудей дуба монгольского и ягод брусники (Vaccinium vitis-idaea L.), что подтверждается исследованиями на данной территории (Середкин и др., 2012).

\section{Перекрывание участков обитания соседствуюших особей}

Большая степень перекрывания участков взрослых самцов с самками по сравнению с участками соседствующих взрослых самцов объясняется особенностями социальной структуры популяции бурого медведя. Доминантный самец, по мнению В.С. Пажетнова (1990), контролирует взаимоотношения особей внутри парцеллы, в состав которой могут входить несколько взрослых самок. Структура группировки обусловливает то обстоятельство, что участок взрослого самца размерами превосходит участки других соподчиненных ему животных и может включать в себя участки нескольких взрослых самок и молодых животных. Есть также мнение, что наличие зоны перекрывания участков обитания самок и ограниченное количество доступных мест обитания увеличивают вероятность размножения самца с самками, устраняя необходимость увеличения дальности перемещений и размеров участков обитания (Barnes, 1990).

Наличие перекрывания участков обитания как между взрослыми самцами (рис. 2), так и взрослыми самками демонстрирует, что на одной территории могут обитать особи не только разного пола и возраста, но и взрослые особи одного пола. Особенно толерантными к присутствию друг друга медведи становятся в местах с высоким обилием пищи (Schoen et al., 1986; Barnes, 1990; Ревенко, 1993; Середкин и др., 2012; Seryodkin et al., 2017). Несомненно, участки обитания меченых особей перекрывались не только между собой, но и с участками немеченых медведей.

Наше исследование показало, что ядерные зоны соседствующих меченых особей либо не перекрывались совсем, либо перекрывались незначительно (табл. 3), что может указывать на наличие у животных небольших по площади предпочитаемых зон, редко посещаемых другими медведями.

\section{Заключение}

Применение радиотелеметрии позволило охарактеризовать ранее недостаточно изученные аспекты экологии бурого медведя на Сихотэ-Алине, связанные с использованием пространства. Изложенный материал демонстрирует характер использования участков обитания животными и представляет значительную ценность.

Участки обитания бурых медведей на Сихотэ-Алине отличаются большими раз- 
мерами по сравнению с другими регионами Дальнего Востока, где ранее проводили исследования с помощью радиотелеметрии. Средний размер годовых участков обитания составил 891,34 и 349,94 км² для взрослых самцов и самок соответственно. Максимальным был двухлетний участок самца площадью 9217,36 км². Размер ядерных зон годовых участков медведей варьировал в широких пределах. Для самцов он был в среднем меньше размера участков обитания в 8 раз, а для самок - в 14,8 раза. Показано, что на исследуемой территории участки обитания самцов больше таковых самок, что в целом характерно для бурых медведей.

Участки обитания медведей в 39 \% случаев состояли из одного полигона, в остальных случаях их было от двух до шести. Часть годовых участков обитания не выходила за пределы одного из речных бассейнов, тогда как для всех медведей, наблюдавшихся двухи трехлетние периоды, водоразделы не являлись преградами.

Структура участков обитания и их ядер, количество и расположение полигонов в них зависят от сезонного выбора медведями местообитаний, распределения, обилия и доступности кормов. Распределение основных нажировочных кормов (орехов сосны корейской и желудей дуба монгольского) на Сихотэ-Алине неравномерно, что обусловли- вает переходы медведей в поисках обильной пищи.

Значительное перекрывание двух годовых участков у одного из взрослых самцов указывает на способность медведей держаться определенной территории из года в год. У других медведей изменение границ участка может быть связано с расширением используемого пространства или с временными заходами на сопредельные территории в поисках пищи.

Перекрывание участков обитания между взрослыми самцами и самками обусловлено социальной структурой популяции медведей. Перекрывание участков соседствующих самцов также присутствует, но между мечеными животными оно много меньшей, особенно в отношении ядерных зон. Это уменьшает напряженность конкурентных отношений между взрослыми особями одного пола.

Преобразование местообитаний и масштабное изъятие человеком кормового ресурса медведей - сосновых орехов (Юдин, 1993; Середкин, Пикунов, 2009) оказывают влияние на состояние популяции и экологию животных, в том числе на использование ими пространства. Грамотное управление популяцией бурого медведя на Сихотэ-Алине, гарантирующее ее сохранение, должно учитывать результаты научных исследований и включать ведение мониторинга состояния популяции и ее экологических параметров.

\section{Благодарности / Acknowledgements}

За помощь в осуществлении полевых исследований авторы благодарят сотрудников Сихотэ-Алинского заповедника и Общества сохранения диких животных. Работа выполнена в рамках госзадания Минобрнауки РФ (№ AАAА-A19-119030790003-1).

The authors are grateful to the staff of the Sikhote-Alin Reserve and the Wildlife Conservation Society. The study was performed in accordance with the state assignment of the Ministry of Education and Science of the Russian Federation (No. AAAA-A19-119030790003-1). 


\section{Список литературы / References}

Абрамов В.К. (1972) Миграции медведей юга Дальнего Востока СССР. Экология, морфология, охрана и использование медведей. М., Наука, с. 6-8 [Abramov V.K. (1979) Migrations of bears in the south of the Far East of the USSR. Ecology, morphology, protection and use of bears. Moscow, Nauka, p. 6-8 (in Russian)]

Бобырь Г.Я. (1991) Роль бурого медведя в использовании ресурсов травянистых растений на Северном Кавказе. Медведи в СССР. Новосибирск, Наука, с. 95-111 [Bobyr G.Y. (1991) The role of the brown bear in the use of herbaceous plant resources in the North Caucasus. Bears in the USSR. Novosibirsk, Nauka, p. 95-111 (in Russian)]

Бромлей Г.Ф. (1965) Медведи юга Дальнего Востока СССР. М.-Л., Наука, 119 с. [Bromley G.F. (1965) Bears in the south of the Far East of the USSR. Moscow, Leningrad, Nauka, 119 p. (in Russian)]

Ветренников В.В. (1976) Геологическое строение Сихотэ-Алинского заповедника и Центрального Сихотэ-Алиня. Владивосток, Дальневосточное книжное издательство, 167 с. [Vetrennikov V.V. (1976) Geological structure of the Sikhote-Alin Reserve and the Central SikhoteAlin. Vladivostok, Dalnevostochnoe knizhnoe izdatelstvo, 167 p. (in Russian)]

Жиряков В.А., Грачев Ю.А. (1993) Бурый медведь. Центральная Азия и Казахстан. Медведи: бурый медведь, бельий медведь, гималайский медведь. М., Наука, с. 170-206 [Zhiryakov V.A., Grachev Y.A. (1993) Brown bear. Central Asia and Kazakhstan. Bears: brown bear, polar bear, Asiatic black bear. Moscow, Nauka, p. 170-206 (in Russian)]

Клевезаль Г.А. (1988) Регистрирующие структуры млекопитающих в зоологических исследованиях. М., Наука, 288 с. [Klevezal G.A. (1988) Mammalian recording structures in zoological studies. Moscow, Nauka, 288 p. (in Russian)]

Кучеренко С.П. (1983) Экология и промысел бурого медведя на Дальнем Востоке. Экология и промысел охотничьих животных. М., Наука, с. 123-131 [Kucherenko S.P. (1983) Ecology of and hunting for the brown bear in the Far East. Ecology of and hunting for game. Moscow, Nauka, p. 123131 (in Russian)]

Мордосов И.И. (1993) Бурый медведь. Якутия. Медведи: бурый медведь, бельій медведь, гималайский медведь. М., Наука, с. 301-318 [Mordosov I.I. (1993) Brown bear. Yakutia. Bears: brown bear, polar bear, Asiatic black bear. Moscow, Nauka, p. 301-318 (in Russian)]

Пажетнов В.С. (1990) Бурый медведь. М., Агропромиздат, 215 с. [Pazhetnov V.S. (1990) Brown bear. Moscow, Agropromizdat, 215 p. (in Russian)]

Ревенко И.А. (1993) Бурый медведь. Камчатка. Медведи: бурый медведь, белый медведь, гималайский медведь. М., Наука, с. 380-403 [Revenko I.A. (1993) Brown bear. Kamchatka. Bears: brown bear, polar bear, Asiatic black bear. Moscow, Nauka, p. 380-403 (in Russian)]

Середкин И.В. (2014) Применение радиотелеметрии и спутникового слежения для изучения использования территории дикими животными на Дальнем Востоке России. Apeaлbl, миграчии и другие перемещения диких животных. Владивосток, Рея, с. 292-299 [Seryodkin I.V. (2014) Application of radio telemetry and satellite tracking for the territory use study of wild animals in the Russian Far East. Distribution, migration and other movements of wildlife. Vladivostok, Reya, p. 292-299 (in Russian)] 
Середкин И.В. (2015) Сравнительный анализ спектров питания бурого и гималайского медведей на Среднем Сихотэ-Алине. Известия Иркутского государственного университета. Серия “Биология. Экология”, 14: 32-38 [Seryodkin I.V. (2015) Diet composition of brown bear and Asiatic black bear in the Middle Sikhote-Alin (Russian Far East): comparative study. The Bulletin of Irkutsk State University. Series "Biology. Ecology" [Izvestiya Irkutskogo Gosudarstvennogo Universiteta. Seriya "Biologiya. Ekologiya"], 14: 32-38 (in Russian)]

Середкин И.В., Костыря А.В., Гудрич Д.М. (2014) Суточные и сезонные перемещения бурого медведя на Сихотэ-Алине. Вестник Тверского государственного университета. Серия "Биология и экология”, 4: 233-240 [Seryodkin I.V., Kostyria A.V., Goodrich J.M. (2014) Daily and seasonal movements of brown bear in the Sikhote-Alin. Herald of Tver State University. Series: Biology and Ecology [Vestnik Tverskogo gosudarstvennogo universiteta. Seriya "Biologiya i Ekologiya"], 4: 233240 (in Russian)]

Середкин И.В., Костыря А.В., Гудрич Д.М., Шляер Б.О., Микелл Д.Г., Керли Л.Л., Квигли К.С., Квигли Х.Б. (2005) Отлов и иммобилизация гималайских и бурых медведей с целью радиомечения. Зоологический журнал, 84(12): 1508-1515 [Seryodkin I.V., Kostyrya A.V., Goodrich D.M., Schleyer B.O., Miquelle D.G., Kerley L.L., Quigley K.S., Quigley H.B. (2005) Capture and immobilization of Asiatic black and brown bears for radio marking. Journal of Zoology [Zoologicheskiy Zhurnal], 84(12): 1508-1515 (in Russian)]

Середкин И.В., Пачковский Дж. (2006) Отлов, иммобилизация и мечение бурого медведя на Камчатке. Сохранение биоразнообразия Камчатки и прилегающих морей. ПетропавловскКамчатский, Камчатпресс, с. 203-206 [Seryodkin I.V., Paczkowski J. (2006) Capture, immobilization and marking of brown bears in Kamchatka. Conservation of Biodiversity of Kamchatka and Coastal Waters. Petropavlovsk-Kamchatsky, Kamchatpress, p. 203-206 (in Russian)]

Середкин И.В., Пикунов Д.Г. (2009) Охрана и использование бурого медведя СихотэАлиня. Известия Самарского научного иентра Российской академии наук, 11 (1(2)): 162-166 [Seryodkin I.V., Pikunov D.G. (2009) Brown bear protection and use in the Sikhote-Alin. Izvestia of Samara Scientific Center of the Russian Academy of Sciences [Izvestiya Samarskogo nauchnogo tsentra Rossiyskoy akademii nauk], 11 (1(2)): 162-166 (in Russian)]

Середкин И.В., Пикунов Д.Г., Костыря А.В., Гудрич Д.М. (2012) Осенний период в жизни медведей в Сихотэ-Алинском заповеднике. Сихотэ-Алинский биосферный район: состояние экосистем и их компонентов. Владивосток, Дальнаука, с. 216-230 [Seryodkin I.V., Pikunov D.G., Kostyria V.A., Goodrich J.M. (2012) The fall season in the lives of bears in the Sikhote-Alin. SikhoteAlin biosphere district: state of ecosystems and their components. Vladivostok, Dalnauka, p. 216-230 (in Russian)]

Юдин В.Г. (1993) Бурый медведь. Юг Дальнего Востока. Медведи: бурый медведь, белый медведь, гималайский медведь. М., Наука, с. 348-380 [Yudin V.G. (1993) Brown bear. South of the Far East. Bears: brown bear, polar bear, Asiatic black bear. Moscow, Nauka, p. 348-380 (in Russian)]

Baddeley A., Turner R. (2005) Spatstat: an R package for analyzing spatial point patterns. Journal of Statistical Software, 12(6): 1-42

Barnes V.G. (1990) The influence of salmon availability on movements and range of brown bears on Southwest Kodiak Island. International Conference on Bear Research and Management, 8: 305-313 
Berns V.D., Atwell G.C., Boone D.L. (1980) Brown bear movements and habitat use at Karluk Lake, Kodiak Island. International Conference on Bear Research and Management, 4: 293-296

Bjarvall A., Sandegren F., Wabakken P. (1990) Large home ranges and possible early sexual maturity in Scandinavian bears. International Conference on Bear Research and Management, 8: 237-241

Blanchard B.M., Knight R.R. (1991) Movements of Yellowstone grizzly bears. Biological Conservation, 58(1): 41-67

Burt W.H. (1943) Territoriality and home range concepts as applied to mammals. Journal of Mammalogy, 24(3): 346-352

Calenge C. (2006) The package "adehabitat" for the R software: a tool for the analysis of space and habitat use by animals. Ecological Modelling, 197(3-4): 516-519

Collins G.H., Kovach S.D., Hinkes M.T. (2005) Home range and movements of female brown bears in southwestern Alaska. Ursus, 16(2): 181-189

Core area tutorial code and data (2017) http://www.stat.colostate.edu/ hooten/other/corearea tutorial_code.txt.

Dahle B., Swenson J.E. (2003) Home ranges in adult Scandinavian brown bears (Ursus arctos): effect of mass, sex, reproductive category, population density and habitat type. Journal of Zoology, 260: $329-335$

Fieberg J. (2014) Home range overlap indices implemented using kernel density estimators with plug-in smoothing parameters and Program R. University of Minnesota Digital Conservancy, doi. org/10.13020/D6G59W

Fieberg J., Kochanny C.O. (2005) Quantifying home-range overlap: the importance of the utilization distribution. Journal of Wildlife Management, 69(4): 1346-1359

Fortin J.K., Rode K.D., Hilderbrand G.V., Wilder J., Farley S., Jorgensen C., Marcot B.G. (2016) Impacts of human recreation on brown bears (Ursus arctos): A review and new management tool. PLoS One, 11(1): e0141983

Gitzen R.A., Millspaugh J.J. (2003) Comparison of least-squares cross-validation bandwidth options for kernel home-range estimation. Wildlife Society Bulletin, 31(3): 823-831

Gitzen R.A., Millspaugh J.J., Kernohan B.J. (2006) Bandwidth selection for fixed-kernel analysis of animal utilization distributions. Journal of Wildlife Management, 70(5): 1334-1344

Glenn L.P., Miller L.H. (1980) Seasonal movements of an Alaskan Peninsula brown bear population. International Conference on Bear Research and Management, 4: 307-312

Gula R., Frackowiak W., Perzanowski K. (1998) Current status and conservation needs of brown bears in the Polish Carpathians. Ursus, 10: 81-86

Jerina K., Debeljak M., Džeroski S., Kobler A., Adamič M. (2003) Modelling the brown bear population in Slovenia: A tool in the conservation management of a threatened species. Ecological Modelling, 170(2-3): 453-469

Jonkel J.J. (1993) A manual for handling bears for managers and researchers. Bozeman, MT, Interagency Grizzly Bear Study Team, Montana State University, 175 p.

Kernohan B.J., Gitzen R.A., Millspaugh J.J. (2001) Analysis of animal space use and movements. Radio tracking and animal populations. San Diego, California, USA, Academic Press, p. 125-166

Kreeger T.J. (1996) Handbook of wildlife chemical immobilization. Wyoming, International Wildlife Veterinary Sciences, Inc. Laramie, 342 p. 
Mano T. (1994) Home range and habitat use of brown bears in the southwestern Oshima Peninsula, Hokkaido. International Conference on Bear Research and Management, 9: 319-325

Martin A.D., Quinn K.M. (2006) Applied Bayesian inference in R using MCMCpack. $R$ News, 6: 2-7

McLoughlin P.D., Case R.L., Gau R.J., Ferguson S.H., Messier F. (1999) Annual and seasonal movement patterns of barren-ground grizzly bears in central Northwest Territories. Ursus, 11: 79-86

McNab B.K. (1963) Bioenergetics and the determination of home range size. American Naturalist, 97: $133-140$

Minta S.C. (1993) Sexual differences in spatio-temporal interaction among badgers. Oecologia, 96(3): 402-409

Pearson A.M. (1975) The northern interior grizzly bear (Ursus arctos L.). Canadian Wildlife Service. Report Series. №34. Ottawa, 86 p.

Pop I.M., Sallay A., Bereczky L., Chiriac S. (2012) Land use and behavioral patterns of brown bears in the south-eastern Romanian Carpathian Mountains: A case study of relocated and rehabilitated individuals. Procedia Environmental Sciences, 14: 111-122

Popescu V.D., Iosif R., Pop M.I., Chiriac S., Bouroș G., Furnas B.J. (2017) Integrating sign surveys and telemetry data for estimating brown bear (Ursus arctos) density in the Romanian Carpathians. Ecology and Evolution, 7(18): 7134-7144

Powell R.A. (2000) Animal home ranges and territories and home range estimators. Research techniques in animal ecology. New York, USA, Columbia University Press, 442 p.

Proctor M.F., McLellan B.N., Strobeck C. (2002) Population fragmentation of grizzly bears in southeastern British Columbia, Canada. Ursus, 13: 153-160

$R$ Development Core Team. $R$ : a language and environment for statistical computing (2015) Vienna, Austria, R Foundation for Statistical Computing, ISBN 3-900051-07-0, URL: http://www.Rproject.org

Reynolds H.V. (1980) North slope grizzly bear studies. Juneau, Alaska, USA, Alaska Department of Fish and Game

Rigg R. (2005) A review of studies on brown bear (Ursus arctos) ecology in relation to home range, habitat selection, activity patterns, social organization, life histories and population dynamics. Oecologia Montana, 14: 47-59

Robert K., Garant D., Pelletier F. (2012) Keep in touch: does spatial overlap correlate with contact rate frequency? Journal of Wildlife Management, 76(8): 1670-1675

Rowlingson B.S., Diggle P.J. (1993) SPLANCS: spatial point pattern analysis code in S-Plus. Computers and Geosciences, 19(5): 627-655

Russell R.H., Nolan J.W., Woody N.G., Anderson G. (1979) A study of the grizzly bear (Ursus arctos L.) in Jasper National Park, 1975-78 final report. Edmonton, Alberta, Canada, Canadian Wildlife Service

Sato Y., Kobayashi Y., Urata T., Takatsuki S. (2008) Home range and habitat use of female brown bear (Ursus arctos) in Urahoro, eastern Hokkaido, Japan. Mammal Study, 33: 99-109

Schoen J.W., Lentfer J.W., Beier L. (1986) Differential distribution of brown bears on Admiralty Island, Southeast Alaska: a preliminary assessment. International Conference on Bear Research and Management, 6: 1-5 
Servheen C. (1983) Grizzly bear food habits, movements, and habitat selection in the Mission Mountains, Montana. Journal of Wildlife Management, 47(4): 1026-1035

Seryodkin I.V., Paczkowski J., Borisov M.Y., Petrunenko Y.K. (2017) Home range of brown bears on the Kamchatka Peninsula and Sakhalin Island. Contemporary Problems of Ecology, 10(6): 599-611

Seryodkin I.V., Zaitsev V.A., Petrunenko Y.K. (2014) Pulsar satellite radio beacon application experience in the telemetry of brown bear (Ursus arctos L.). Achievements in the Life Sciences, 8(1): 43-46

Skuban M., Find'o S., Kajba M. (2016) Human impacts on bear feeding habits and habitat selection in the Polana Mountains, Slovakia. European Journal of Wildlife Research, 62(3): 353-364

Smith T.S. (2002) Effects of human activity on brown bear use of the Kulik River, Alaska. Ursus, 13: $257-267$

Van Winkle W. (1975) Comparison of several probabilistic home range models. Journal of Wildlife Management, 39(1): 118-123

Venables W.N., Ripley B.D. (2002) Modern applied statistics with S. New York, USA, Springer, $498 \mathrm{p}$.

Wakkinen W.L., Kasworm W.F. (2004) Demographics and population trends of grizzly bears in the Cabinet Yaak and Selkirk Ecosystems of British Columbia, Idaho, Montana and Washington. Ursus, 15(1): 65-75

Wilson R.R., Hooten M.B., Strobel B.N., Shivik J.A. (2010) Accounting for individuals, uncertainty, and multi-scale clustering in core area estimation. Journal of Wildlife Management, 74(6): 1343-1352

Worton B.J. (1989) Kernel methods for estimating the utilization distribution in home-range studies. Ecology, 70(1): 164-168

Zedrosser A., Gerstl N., Rauer G. (1999) Brown bears in Austria: 10 years of conservation and actions for the future. Vienna, Federal Environment Agency, 42 p. 